International Journal of Economics, Business and Accounting Research (IJEBAR)

Peer Reviewed - International Journal

Vol-4, Issue-1, 2020 (IJEBAR)

E-ISSN: 2614-1280 P-ISSN 2622-4771

https://jurnal.stie-aas.ac.id/index.php/IJEBAR

\title{
COMMERCIAL BANKING PERFORMANCE AND ECONOMIC GRPWTH: THE CASE OF TUNISIA BETWEEN 1990-2018
}

\author{
IMED MTIR ${ }^{1}$, NIZAR BEN ABDALLAH ${ }^{2}$ \\ Jazan University, College of Business Administration \\ E-mail: imtir@jazanu.edu.sa \\ nbenabdallah@jazanu.edu.sa
}

\begin{abstract}
In this paper, we propose to assess the efficiency scoretechniques of 10 Tunisian commercial banks for the period cover 1990 to 2018. The local banking landscape was marked, during the period studied, by significant changes following the adoption by the Tunisian government, of various financial liberalization measures as well as the period of the subprime crisis and then the revolution of 2011. Given studying the technical efficiency levels achieved by Tunisian commercial banks, we propose a non-parametric method, the approach DEA, data envelopment analysis, on the one hand, and the determination of the variables explaining the level of performance on the other. Our results allow us to conclude that the banks which obtained the best average efficiency scores are: Amen Bank (100\%) and Arab Tunisian Bank (98.9\%). Whereas, other banks are considered inefficient. To study the impact of banking performance indicators, a variable that measures the crisis, Equity, total assets, and total liabilities on the efficiency scores calculated by the DEA methodology, return on assets (ROA) and return on equity (ROE), we used an ECM error correction model in panel data. The results show the positive impacts of these indicators on banking performance in Tunisia.
\end{abstract}

Keywords: $\quad$ Commercial Banks, Efficiencies, DEA.

JEL classification: $C 01, C 23, C 67, G 14, G 21$

\section{Introduction}

The Tunisian banking system has undergone profound and rapid changes and mutations since the 1970s. Several phenomena explain these changes, such as the proliferation of financial innovations created by private actors and the reforms adopted by public authorities. Liberalization and modernization of banking systems are the main objectives of these reforms. Likewise, the latter was at the heart of the major problem of financial instability recognized by several economies around the world. In this sense, Tunisia started with a phenomenon of financial globalization which allows the transfer of capital which results in the growth of investments and productivity gains. Likewise, this globalization improves economic growth through the reduction of investment costs, the increase of domestic savings, the transfer of the most sophisticated technologies and the development of domestic financial sectors.

Besides, technological innovations were at the heart of major changes in the Tunisian banking system in the sense that these innovations help to overcome the geographical barriers between the national and international financial markets and they develop new information and communication technology as well as the development of remote banking. Also, the movement of deregulation of the financial system, which leads to the development of new products and new financial functions, 
International Journal of Economics, Business and Accounting Research (IJEBAR)

Peer Reviewed - International Journal

Vol-4, Issue-1, 2020 (IJEBAR)

E-ISSN: 2614-1280 P-ISSN 2622-4771

https://jurnal.stie-aas.ac.id/index.php/IJEBAR

has been the basis for the development of direct finance. Besides, financial capitalism has contributed to a strong growth of the Tunisian economy in recent years when shareholders have regained strategic power. In other words, the modernization of banking systems can bring efficiency gains and in terms of risk management and also in terms of a financial watch. But, on the other hand, it can be the source of serious financial problems and dysfunctions, which explains the emergence of financial crises. Besides, the main goal of any economy in a country is to limit the consequences that generate these changes, to preserve the long-term financing of essential investments and to ensure sound banking and financial governance to rebuild a stable and socially acceptable environment.

Also, the stability of the banking system plays a very important role in supporting financial development in the sense that banks provide liquidity and financial solutions. However, this contribution is linked to a remarkable condition which is banking performance and efficiency. Banks are still looking for good performance and very significant efficiency gains. This banking objective can be supported by favorable economic conditions that improve the results of banking institutions. To achieve this, banks rely heavily on good governance because it is a guarantee of all good banking performance and any minimization of internal and external risk levels. Likewise, the performance and efficiency of banks allow the real sphere to function properly in the sense that, through intermediation, they offer more liquidity and facilitate the transactions of economic agents. By marking remarkable gains and economies of scale, banking institutions are contributing in one way or another to economic growth. The more efficient the bank, the more economic growth increases at a very remarkable rate, the contribution of the banking system to overall growth weighstoo heavily.

\section{Literature Review}

The question of banking performance and its relationship with the economic growth of countries reveals very importantly among practitioners and actors where M.Chaffai and P. Coccorese 2019 see that banking performance is directly linked to the efficiency of management within banks which is conditioned by the existence of highly qualified human capital. Similarly, T. Fufa and J. Kim 2017 indicated that the link between financial development, conditioned by the stability of the banking system, and economic growth depends on the stages of economic growth in countries. Besides, D. Durusu-Ciftsi, M. SerdarIspir and H. Zetkiner 2017 concluded that debt from credit markets and stock market actions positively affect the level of GDP per capita at steady-state and that the contribution of the credit markets is greater. In addition, S. Ben Naceur and S Ghazouani 2008 arrived at a negative association between banking development and economic growth after controlling the development of the stock market whose relationship is linked to the sub-financial systemsdeveloped in the MENA region which impede economic growth. Also, F. Bremus and C. M. Buch 2017 have shown that if the markets are very concentrated in terms of the size distribution of banks, idiosyncratic shocks at the level of banks do not cancel each other out, but can affect macroeconomic results. Likewise, financial openness can affect GDP growth per se, but also concentration in the banking sector and, therefore, the impact of bank-specific shocks on the overall economy.

Using panel data on Tunisian and Turkish banks, H. Moussa 2008 showed that weaker performing banks are more poorly managed and that the creation of appropriate institutions and laws would force delinquent banks to improve their governance to then reach high-profit levels and have 
International Journal of Economics, Business and Accounting Research (IJEBAR)

Peer Reviewed - International Journal

Vol-4, Issue-1, 2020 (IJEBAR)

E-ISSN: 2614-1280 P-ISSN 2622-4771

https://jurnal.stie-aas.ac.id/index.php/IJEBAR

more liquidity to be able to finance the real sphere. In addition, B. Hmissi, A. Bejaoui and W. Snoussi 2017, through the calculation of systemic risk, classified Tunisian banks as systemically important banks in the Tunisian banking system where Tunisian public banks constitute the riskiest systemic banking sector and that its contribution to Tunisian economic growth is the lowest by comparing it to that of Tunisian private banks. In addition, L. Otero González, A. Razia, M. VivelBúa and R. LadoSestayo 2019 have shown that banks with a larger market share get higher profits which increases bank profitability.

However, there are still highly concentrated markets in which banks are less profitable and more inefficient, which affects the competitiveness of the banking system and therefore slows the pace of economic growth. Also, K. Ben Jedidia, T. Boujelbène and K. Helali 2014 concluded that financial development is an engine of long-term economic growth in the sense that domestic credit to the private sector had a positive effect on economic growth and it is subject to short-term financial fragility. However, they found that neither stock development nor bank intervention in the stock market had strong and positive effects on economic growth. N. Petria, B. Capraru and I. Ahnatov 2015 noted that management efficiency, market concentration/competition, credit and liquidity risk and diversification of activities influence the profitability of banks, both on ROA than on ROE and that competition positively influences the profitability of banks.

P. K Narayan, S. Narayan 2013 detected that neither the banking nor the financial sector contributes to growth in the countries of the Middle East. The development of the financial sector on economic growth is relatively weak except for Asia and that bank credit has a statistically significant and negative effect on economic growth except for the countries of the Middle East. Finally, M. Kar, S. Nazlıoğlu and H. Ağir 2011 concluded that there is no clear consensus on the causal link between financial development and economic growth for all measures of financial development and it is also observed that the results are specific to each country.

\section{Empirical Evidence}

In this work, we will calculate the technical efficiency scores of commercial banks in Tunisia with the DEA methodology.

\subsection{Empirical results}

Our sample consists of the following 10 banks for the period between 1990-2018:

\begin{tabular}{|l|l|l|l|l|}
\hline $\begin{array}{l}\text { National Bank } \\
\text { Agriculture ( } \\
\text { BNA) }\end{array}$ & $\begin{array}{l}\text { Tunisian bank } \\
\text { company (STB) }\end{array}$ & $\begin{array}{l}\text { International } \\
\text { Arab Bank of } \\
\text { Tunisia (BIAT) }\end{array}$ & $\begin{array}{l}\text { habitat bank } \\
(\mathrm{BH})\end{array}$ & $\begin{array}{l}\text { International } \\
\text { Union of Banks } \\
\text { (UIB) }\end{array}$ \\
\hline Attijari Bank & $\begin{array}{l}\text { Bank of Tunisia } \\
\text { (BT) }\end{array}$ & $\begin{array}{l}\text { The Banking } \\
\text { Union for } \\
\text { Commerce and } \\
\text { Industry (UBCI) }\end{array}$ & Amen Bank & $\begin{array}{l}\text { Arab Tunisian } \\
\text { Bank (ATB) }\end{array}$ \\
\end{tabular}

\subsection{Choice of inputs and outputs}

The selection of inputs and outputs calls into question the power of DEA in discriminating between units. Each resource used by a unit must be included as input and the latter will convert the resources to produce outputs. Several factors can be considered as inputs.In our analysis, we will measure the technical efficiency of Tunisian commercial banks. 
International Journal of Economics, Business and Accounting Research (IJEBAR)

Peer Reviewed - International Journal

Vol-4, Issue-1, 2020 (IJEBAR)

E-ISSN: 2614-1280 P-ISSN 2622-4771

https://jurnal.stie-aas.ac.id/index.php/IJEBAR

Table 1: Inputs and outputs selected

\begin{tabular}{|l|l|}
\hline Inputs & Outputs \\
\hline$X 1:$ demand deposit & $Y:$ Net banking income \\
\hline$X 2:$ a term deposit & \\
\hline
\end{tabular}

\subsection{Efficiency Scores of Tunisian Commercial Banks}

We use the DEA model in the case of constant returns to scale to measure the efficiency of Tunisian commercial banks. The results obtained by the DEAP1.2 software are represented in the table 2:

Table 2: Efficiency scores measured in the case of constant returns to scales (average score)

\begin{tabular}{|l|l|}
\hline Banks & Efficiency scores \\
\hline BNA & 0.921 \\
\hline STB & 0.848 \\
\hline BIAT & 0.944 \\
\hline BH & 0.917 \\
\hline UIB & 0.964 \\
\hline Attijari Bank & 0.964 \\
\hline BT & 0.947 \\
\hline UBCI & 0.968 \\
\hline Amen Bank & $\underline{1.000}$ \\
\hline ATB & 0.989 \\
\hline
\end{tabular}

In the case of constant returns to scales, it can be seen that Amen Bank has the highest technical efficiency score among the representative sample of Tunisian commercial banks. Indeed, Amen Bank is considered as the most efficient bank which ensures a better combination between the inputs (namely demand deposits and term deposits) to achieve the maximum output (ie net banking product), since its efficiency score is 1,000. The STB is the least efficient bank which, by combining sight deposits and term deposits, achieves a lower level of net banking income, since its efficiency score is the lowest (equal to 0.848).

The graphical representation of the efficiency border of Tunisian commercial banks is given as figure 1: 
International Journal of Economics, Business and Accounting Research (IJEBAR)

Peer Reviewed - International Journal

Vol-4, Issue-1, 2020 (IJEBAR)

E-ISSN: 2614-1280 P-ISSN 2622-4771

https://jurnal.stie-aas.ac.id/index.php/IJEBAR

Figure1: Technical efficiency of Tunisian commercial banks between 1990-2018

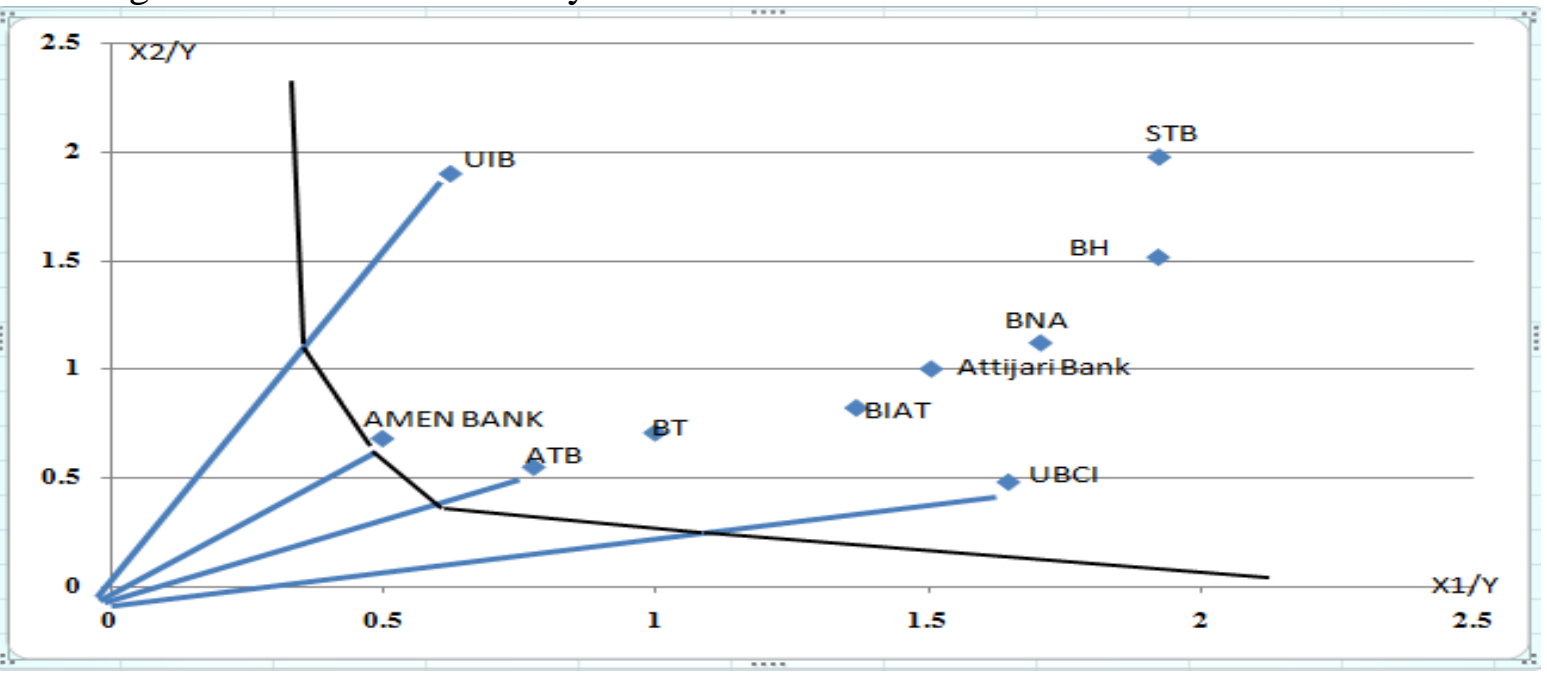

Note that Amen Bank is located on an efficient border since it is the most efficient with a score equal to 1 . The banks' UIB, ATB, and UBCI are the closest to the efficient border. The STB bank is furthest from the efficient frontier.

\section{Empirical validation of the performance of Tunisian commercial bank}

The variables used to measure banking performance in Tunisia are as follows:

- ROA: represents the performance indicator, namely return on assets which are equal to the ratio of net banking profit to total banking assets.

- ROE: represents the indicator of return on equity which is equal to the ratio of net banking income to bank equity.

- Efficiency: the efficiency scores calculated from the DEA methodology which is equal to the ratio of bank sight deposits to bank term deposits.

- Crisis: which is equal to the ratio of bank loans to bank funds (short and long term deposits and any other funds the bank has in the short term).

- Equity: The financial resources available to the bank (excluding debts). Total assets: All assets, securities or property belonging to the bank.

- Total liabilities: All of the resources that enabled the expenses appearing in the assets.

In this section, we will estimate the impact of indicators of banking performance on Return on Assets (ROA), return on equity (ROE) and the technical efficiency of Tunisian commercial banks. To meet our objective of explaining banking performance using different indicators, we are developing the following models:

ROA $\mathrm{it}=\alpha_{0}+\alpha_{1} *$ crisis $+\alpha_{2} *$ Equity $+\alpha_{3} *$ total assets $+\alpha_{4} *$ total liabilities $+\mathrm{U}_{\mathrm{it}}$ $\mathrm{ROE}_{\mathrm{it}}=\alpha_{0}+\alpha_{1} *$ crisis $+\alpha_{2} *$ Equity $+\alpha_{3} *$ total assets $+\alpha_{4} *$ total liabilities $+\mathrm{U}_{\text {it }}$ Efficiency $\mathrm{itt}_{1}=\alpha_{0}+\alpha_{1} *$ crise $+\alpha_{2} *$ Equity $+\alpha_{3} *$ total assets $+\alpha_{4} *$ total liabilities $+\mathrm{U}_{\mathrm{it}}$ 
International Journal of Economics, Business and Accounting Research (IJEBAR)

Peer Reviewed - International Journal

Vol-4, Issue-1, 2020 (IJEBAR)

E-ISSN: 2614-1280 P-ISSN 2622-4771

https://jurnal.stie-aas.ac.id/index.php/IJEBAR

Our database is extracted from the bank reports of 10 Tunisian commercial banks for a period spanning between 1990 and 2018, these estimates are made by Eviews software.

\subsection{Stationary study}

The series used are transformed into logarithms of the variables crisis, equity, technical efficiency of Tunisian banks, total assets, total liabilities, return on assets and return on equity, during a period spanning between 1990-2018. Based on the "Eviews 7" software, and knowing that the stationary study of these series carried out by the ADF test. The estimated results of the unit root test are assumed in the table 3:

Table 3: Unit Root Test (First level)

\begin{tabular}{|l|l|l|l|l|l|l|l|}
\hline & Equity & Crisis & Efficiency & ROA & ROE & $\begin{array}{l}\text { Total } \\
\text { assets }\end{array}$ & $\begin{array}{l}\text { Total } \\
\text { liabilities }\end{array}$ \\
\hline ADF & -1.18 & 2.06 & 3.76 & 2.24 & 5.19 & 5.13 & 5.29 \\
\hline Prob & 0.11 & 0.81 & 0.88 & 0.84 & 0.92 & 0.91 & 0.95 \\
\hline
\end{tabular}

We note from the unit root test that the variables are stationary in level and therefore we must ensure the stationary of the variables in first difference, their order of integration as well as test the existence of cointegration relationship.

The stationary tests for all the variables in the first difference and based on the ADF test are presented in the table 4 :

Table 4: Unit Root Test (First differences)

\begin{tabular}{|l|l|l|l|l|l|l|l|}
\hline & dCP & dCrise & dEfficience & dROA & dROE & dTA & dTP \\
\hline ADF & 16.7 & 18.45 & 16.88 & 21.24 & 17.92 & 15.19 & 14.15 \\
\hline Prob & 0.000 & 0.000 & 0.000 & 0.000 & 0.000 & 0.000 & 0.000 \\
\hline
\end{tabular}

We note that the variables are integrated of order 1, they are non-stationary in level and stationary in the first difference.

\subsection{Cointegration test}

The next step of our empirical study is devoted to the study of the cointegration of the variables to be studied for the three equations, ROA, ROE, and Efficiency.

Johansen (1988) developed a multi-varied approach to cointegration based on the maximum likelihood method. He proposed two statistics, namely, the trace test and the maximum Eigen-Value test.Referring to our variables, the results of the trace test are presented in the table 5:

Table 5: Cointegration test

\begin{tabular}{|l|l|l|l|}
\hline & ROA & ROE & Efficiency \\
\hline Panel PP-Statistic & 0.646381 & 0.761937 & -0.837701 \\
& $(0.7410)$ & $(0.7770)$ & $(0.7989)$ \\
& & & \\
\hline Panel ADF-Statistic & 0.639472 & 0.759571 & -1.056948 \\
& $(0.7387)$ & $(0.7762)$ & $(0.8547)$ \\
\hline
\end{tabular}


International Journal of Economics, Business and Accounting Research (IJEBAR)

Peer Reviewed - International Journal

Vol-4, Issue-1, 2020 (IJEBAR)

E-ISSN: 2614-1280 P-ISSN 2622-4771

https://jurnal.stie-aas.ac.id/index.php/IJEBAR

One notes the existence of cointegrationrelation and thus it is necessary to pass to the estimation of the model of the error correction ECM.

\subsection{Error Correction Model}

We note the stationary of the residuals recovered from the static relationship for the three models, which confirms the existence of cointegration and thus the transition to the error correction model.

Table 6 - Econometric results

\begin{tabular}{|c|c|c|c|c|c|c|c|c|}
\hline & \multicolumn{2}{|l|}{ ROE } & \multicolumn{3}{|l|}{$\mathrm{ROA}$} & \multicolumn{3}{|l|}{ Efficiency } \\
\hline & $\begin{array}{r}\text { coefficie } \\
n t\end{array}$ & $\begin{array}{r}\mathrm{t}- \\
\text { sudent }\end{array}$ & variable & $\begin{array}{r}\text { coefficie } \\
\text { nt }\end{array}$ & $\begin{array}{r}\mathrm{t}- \\
\text { sudent }\end{array}$ & variable & $\begin{array}{r}\text { coefficie } \\
n t\end{array}$ & $\begin{array}{r}t- \\
\text { sudent }\end{array}$ \\
\hline $\mathrm{C}$ & 0.008 & 1.862 & $\mathrm{C}$ & 0.007 & 2.17 & $\mathrm{C}$ & 6.184 & 1.66 \\
\hline $\begin{array}{l}\text { RESR } \\
\mathrm{OE}(-1)\end{array}$ & -0.024 & -5.123 & $\begin{array}{r}\text { RESRO } \\
\text { A(-1) }\end{array}$ & -0.63 & -4.503 & $\begin{array}{r}\text { RESEFFICIE } \\
\text { NCY }(-1)\end{array}$ & -0.78 & -1.72 \\
\hline $\begin{array}{r}\text { DROE } \\
(-1)\end{array}$ & 0.345 & 1.435 & $\begin{array}{r}\text { DROA( } \\
-1)\end{array}$ & 0.178 & 2.123 & $\begin{array}{r}\text { DEFFICIENC } \\
\mathrm{Y}(-1)\end{array}$ & -0.04 & -0.05 \\
\hline $\begin{array}{r}\text { DCRI } \\
\text { SIS }\end{array}$ & -0.276 & -1.176 & $\begin{array}{r}\text { DCRISI } \\
\mathrm{S}\end{array}$ & -0.16 & -1.76 & DCRISIS & -0.21 & -1.89 \\
\hline $\begin{array}{r}\text { DCRI } \\
\text { SIS(- } \\
1)\end{array}$ & -0.002 & -1.765 & $\begin{array}{r}\text { DCRISI } \\
\text { S(-1) }\end{array}$ & -0.003 & -1.345 & DCRISIS(-1) & 0.016 & 1.43 \\
\hline $\begin{array}{r}\text { DEQU } \\
\text { ITY }\end{array}$ & 0.346 & 1.987 & $\begin{array}{r}\text { DEQUI } \\
\text { TY }\end{array}$ & 0.287 & 1.65 & DEQUITY & 0.830 & 1.59 \\
\hline $\begin{array}{r}\text { DEQU } \\
\text { ITY(- } \\
1)\end{array}$ & 0.012 & 0.607 & $\begin{array}{c}\text { DEQUI } \\
\text { TY(-1) }\end{array}$ & 0.013 & 0.390 & $\begin{array}{r}\text { DEQUITY(- } \\
1)\end{array}$ & 0.342 & 0.134 \\
\hline $\begin{array}{r}\text { DTOT } \\
\text { AL } \\
\text { ASSE } \\
\text { TS }\end{array}$ & 0.038 & 1.098 & $\begin{array}{r}\text { DTOT } \\
\text { AL } \\
\text { ASSET } \\
\mathrm{S}\end{array}$ & 0.365 & 1.762 & $\begin{array}{r}\text { DTOTAL } \\
\text { ASSETS }\end{array}$ & 0.56 & 1.76 \\
\hline $\begin{array}{r}\text { DTOT } \\
\text { AL } \\
\text { ASSE } \\
\text { TS }(-1)\end{array}$ & -0.029 & -0.342 & $\begin{array}{r}\text { DTOT } \\
\text { AL } \\
\text { ASSET } \\
\text { S(-1) }\end{array}$ & -0.065 & -0.876 & $\begin{array}{r}\text { DTOTAL } \\
\text { ASSETS }(-1)\end{array}$ & -0.24 & -0.198 \\
\hline $\begin{array}{r}\text { DTOT } \\
\text { AL } \\
\text { LIABI } \\
\text { LITIE } \\
\mathrm{S}\end{array}$ & 1.650 & 1.231 & $\begin{array}{r}\text { DTOT } \\
\text { AL } \\
\text { LIABIL } \\
\text { ITIES }\end{array}$ & 1.345 & 1.91 & $\begin{array}{r}\text { DTOTAL } \\
\text { LIABILITIES }\end{array}$ & 1.17 & 1.734 \\
\hline $\begin{array}{r}\text { DTOT } \\
\text { AL }\end{array}$ & -0.82 & -0.867 & $\begin{array}{r}\text { DTOT } \\
\text { AL }\end{array}$ & -0.623 & -0.623 & $\begin{array}{r}\text { DTOTAL } \\
\text { LIABILITIES }\end{array}$ & -6.34 & -0.432 \\
\hline
\end{tabular}


International Journal of Economics, Business and Accounting Research (IJEBAR)

Peer Reviewed - International Journal

Vol-4, Issue-1, 2020 (IJEBAR)

E-ISSN: 2614-1280 P-ISSN 2622-4771

https://jurnal.stie-aas.ac.id/index.php/IJEBAR

\begin{tabular}{|r|r|r|r|r|r|r|}
\hline \hline LIABI \\
LITIE
\end{tabular}

According to our results, there is a positive and significant relationship between the indicators of banking financial development (equity, total assets, and total liabilities) and the return on equity, return on assets and technical banking efficiency. There is a positive and significant relationship between the return on equity, return on assets and the technical banking efficiency and the equity of banks in the sense that an increase in equity of $1 \%$ will lead to an increase in return on equity of 0.346 , an increase in profitability 0.287 and an increase in technical efficiency of 0.83 . So even there is a positive effect of the increase in equity. This effect remains small since Tunisian commercial banks have experienced many difficulties in terms of fundraising because the crisis had negative effects on the Tunisian financial and economic spheres. Likewise, total bank assets have a positive impact on the return on equity where an increase in the total assets of $1 \%$ will lead to an increase in the return on equity of 0.038 , an increase in the return on assets of 0.365 and an increase of the technical efficiency of 0.56 .

This increase is very small given that the profits made by Tunisian commercial banks have decreased considerably following the impact of the financial crisis on Tunisian banking operations abroad. Also, the $1 \%$ increase in total bank liabilities will lead to an increase in the return on equity of 1.65, an increase in the return on assets of 1,34 and an increase in efficiency of 1,17 . This increase is significant in the sense that bank liabilities remained a weapon against financial crises and a guarantee of the persistence of banking activities. In addition, there is also a negative relationship between the variable that measures the crisis and the return on equity, economic and banking efficiency. An increase of the financial crisis by $1 \%$ will lead to a decrease in the return on equity of -0.276 , a decrease in the return on assets of -0.16 and -0.21 on efficiency. The latter is due to the spread of the crisis throughout the world and especially in Tunisia since this country practices liberalization, globalization, and openness to the outside.

\section{Conclusion}

The Tunisian banking system is experiencing a fairly significant change brought about by the initiation of financial liberalization movements, financial globalization, financial disintermediation, and financial capitalism. These movements have brought about great changes and a major reform of the national and international financial sectors. The opening of Tunisia to the outside world and the liberalization of its financial and real sectors are the main causes of the fragility of its banking system in the sense that any outbreak of a financial crisis in any country in the world will transform on Tunisian territory. Tunisia's openness to the outside world makes Tunisian banks more vulnerable to macroeconomic shocks that could lead to their failures. These bank failures, which are at the root of the crises, can also be explained by the speculative behavior of Tunisian banks and their openness to foreign markets.

To illustrate this point, we carried out a study on the performance of Tunisian commercial banks using the DEA method, especially in times of crisis. Our results confirm the economic 
International Journal of Economics, Business and Accounting Research (IJEBAR)

Peer Reviewed - International Journal

Vol-4, Issue-1, 2020 (IJEBAR)

E-ISSN: 2614-1280 P-ISSN 2622-4771

https://jurnal.stie-aas.ac.id/index.php/IJEBAR

literature showing a causal relationship between the financial crisis, known as the subprime crisis, and the fragility of Tunisian commercial banks. Besides, it has been noted that the increase in the equity of these banks has positively affected the efficiency of Tunisian commercial banks, but on a very small scale. This is explained by the negative impact of this crisis on the Tunisian financial and economic sphere. Likewise, Tunisian commercial banks have found many difficulties in terms of their assets which have a positive impact but are not remarkable on banking efficiency. This situation was worsened by the start of the Tunisian revolution in 2011, of which several banks suffered from several financial problems, namely the lack of household deposits and the existence of the parallel market. However, bank liabilities had a remarkable and positive impact on the return on equity, on the economic profitability and the technical efficiency of Tunisian commercial banks.

Also, although the Tunisian banking system is developed and that it is on the threads of technological progress and new banking orientations and structures, it remains fragile and sensitive to financial shocks. In addition to these factors, the problems that have been encountered by Tunisian commercial banks are also due to poor management strategies and fraudulent behavior by leaders which increase banking opacity and facilitate its failure. In general, the fragility of the Tunisian banking system is mainly due to the triggering of speculative bubbles and the conflicts of interest encountered in these banks, that is to say, mismanagement and poor risk control. Hence the need to strengthen the risk management process and the establishment of a system of good governance through prudential banking regulations to maintain the financial stability of these banks.

\section{References}

BochraHmissi, Azzabejaoui, WafaSnoussi2017: On identifying the domestic systemically important banks: The case of Tunisia. Research in International Business and Finance, Elsevier, vol. 42(C), pages 1343-1354.

Dilek Durusu-Ciftci, M. Serdar Ispir, Hakan Yetkiner: Financial development and economic growth: Some theory and more evidence 2017: Journal of Policy Modeling, Elsevier, vol. 39(2), pages 290-306.

Franziska Bremus, Claudia M. Buch: Granularity in banking and growth: Does financial openness matter?2017:Journal of Banking \& Finance, Elsevier, vol. 77(C), pages 300-316.

H. Moussa2008: Inflation Control and Banking Systems: The Case of Tunisia. 2008. The Journal of EconomicAsymmetries, Volume 5, Issue 2, December 2008, Pages 53-71.

Khoutem Ben Jedidia, Thuraya Boujelbène, Kamel Helali2014: Financial development and economic growth: New evidence from Tunisia. Journal of Policy Modeling, vol. 36, issue 5, 883-898.

Luis Otero González, Alaa Razia, MilagrosVivel Búa, RubénLado Sestayo2019: Market structure, performance, and efficiency: Evidence from the MENA banking sector.International Review of Economics\& Finance, Volume 64, November 2019, Pages 84-101.

Mohamed Chaffai, Paolo Coccorese: How far away is the MENA banking system? Efficiencycomparisonswith international banks2019: The North American Journal of Economics and Finance, Volume 49, July 2019, Pages 378-395.

Muhsin Kar, Şaban Nazlığlu, Hüseyin Ağır: Financial development and economic growth nexus in the MENA countries: Bootstrap panel granger causality analysis2011:Economic Modelling: 685693. 
International Journal of Economics, Business and Accounting Research (IJEBAR)

Peer Reviewed - International Journal

Vol-4, Issue-1, 2020 (IJEBAR)

E-ISSN: 2614-1280 P-ISSN 2622-4771

https://jurnal.stie-aas.ac.id/index.php/IJEBAR

Nicolae Petria, Bogdan Capraru, Iulian Ihnatov: Determinants of Banks' Profitability: Evidence from EU 27 Banking Systems2015:ProcediaEconomics and Finance, Volume 20, 2015, Pages 518524.

Paresh Kumar Narayan, Seema Narayan: The short-run relationship between the financial system and economic growth: New evidence from regional panels2013:International Review of Financial Analysis:70-78.

Paul Vera-Gilces, Segundo Camino-Mogro, Xavier Ordeñana-Rodríguez, Gino CornejoMarcos2019: A look insidebankingprofitability: Evidence from a dollarized emerging country.The Quarterly Review of Economics and Finance.

Roman Matkovskyy, Taoufik Bouraoui, Helmi Hammami: Analysing the financial strength of Tunisia2016: An approach to estimate an index of financial safety.Research in International Business and Finance, Volume 38, September 2016, Pages 485-493.

Samy Ben Naceur, Samir Ghazouani: Stock markets, banks, and economic growth: Empirical evidence from the MENA region2008. Journal of Comparative Economics, Volume 36, Issue 4, December 2008, Pages 673-693.

Tolina Fufa, Jaebeom Kim: Stock markets, banks, and economic growth: Evidence from more homogeneous panels2017:Research in International Business and Finance 44.

Wadie Nasri, Lanouar Charfeddine: Factors affecting the adoption of Internet banking in Tunisia2012: An integration theory of acceptance model and theory of planned behavior. The Journal of High Technology Management Research 23(1):1-14. 